\title{
Téoros
}

Revue de recherche en tourisme

\section{Sustainable Tourism: An issue of Territorial Rebalancing in the French département of Pyrénées-Orientales}

\section{Nicolas Berthet}

Numéro hors-série, 2012

Innovations en tourisme durable

Innovations in Sustainable Tourism

URI : https://id.erudit.org/iderudit/1036570ar

DOI : https://doi.org/10.7202/1036570ar

Aller au sommaire du numéro

Éditeur(s)

Université du Québec à Montréal

ISSN

0712-8657 (imprimé)

1923-2705 (numérique)

Découvrir la revue

Citer cet article

Berthet, N. (2012). Sustainable Tourism: An issue of Territorial Rebalancing in the French département of Pyrénées-Orientales. Téoros, 99-103.

https://doi.org/10.7202/1036570ar
Résumé de l'article

Bordered by Spain to the south, between the Mediterranean Sea and the Pyrenees mountains, the French département of Pyrénées-Orientales, also known as Northern Catalonia or French Catalonia, has long seemed to be an outlying rural area, isolated, with very little industry. The advent in the 1960s of the Mission Interministérielle d'Aménagement touristique du littoral du Languedoc-Roussillon (also known as the Racine Mission, after its director, Pierre Racine), would quickly turn the département into a major southern France tourist destination. The dynamic of developing the coastal plain contrasted with the decline of agriculture and the rural exodus taking place in the backcountry. Aware that a preserved rural and natural setting nonetheless had tourism potential, various neo-rural populations moved to the backcountry starting in the 1970s. They developed nature tourism in this area at the beginning of the 1980s. Although it was marginal compared to the activity generated by mass tourism on the coast and at ski resorts, backcountry nature tourism was the starting point for future sustainable tourism development in the Pyrénées-Orientales.

By referring to stakeholder networking initiatives, as well as public transportation policies, this article offers a description of the innovative processes set up and/or maintained by the Conseil Général des Pyrénées-Orientales in the area of sustainable tourism. The outcome of discussions in a professional capacity with various actors in local tourism, this article stresses the importance of the engagement of local authorities, in this case the Conseil Général des Pyrénées-Orientales, to carry through with sustainable development of tourism in a Mediterranean destination that is still largely given over to mass tourism.
Ce document est protégé par la loi sur le droit d'auteur. L'utilisation des services d’Érudit (y compris la reproduction) est assujettie à sa politique d'utilisation que vous pouvez consulter en ligne.

https://apropos.erudit.org/fr/usagers/politique-dutilisation/ 


\title{
Sustainable tourism: An issue of territorial rebalancing in the French département of Pyrénées-Orientales
}

\author{
Nicolas BERTHET \\ Doctoral student \\ Faculty of Tourism, Universitat de Girona (Catalonia) \\ Université de Perpignan (France) \\ nmberthet@gmail.com
}

\begin{abstract}
Bordered by Spain to the south, between the Mediterranean Sea and the Pyrenees mountains, the French département of Pyrénées-Orientales, also known as Northern Catalonia or French Catalonia, has long seemed to be an outlying rural area, isolated, with very little industry. The advent in the 1960s of the Mission Interministérielle d'Aménagement touristique du littoral du Languedoc-Roussillon (also known as the Racine Mission, after its director, Pierre Racine), would quickly turn the département into a major southern France tourist destination. The dynamic of developing the coastal plain contrasted with the decline of agriculture and the rural exodus taking place in the backcountry. Aware that a preserved rural and natural setting nonetheless had tourism potential, various neo-rural populations moved to the backcountry starting in the 1970s. They developed nature tourism in this area at the beginning of the 1980s. Although it was marginal compared to the activity generated by mass tourism on the coast and at ski resorts, backcountry nature tourism was the starting point for future sustainable tourism development in the Pyrénées-Orientales.

By referring to stakeholder networking initiatives, as well as public transportation policies, this article offers a description of the innovative processes set up and/or maintained by the Conseil Général des Pyrénées-Orientales in the area of sustainable tourism. The outcome of discussions in a professional capacity with various actors in local tourism, this article stresses the importance of the engagement of local authorities, in this case the Conseil Général des Pyrénées-Orientales, to carry through with sustainable development of tourism in a Mediterranean destination that is still largely given over to mass tourism.
\end{abstract}

Keywords : destination, sustainable development, heritage, stakeholder, transportation.

For more than 30 years, the concept of sustainable development of tourism has been a major focus of interest for tourism theorists and professionals alike (Sharpley and Telfer, 2000). While everyone accepts the idea of developing integrated tourism, a type of tourism that integrates both territories and people, the very nature of the concept divides researchers and professionals into two camps: the "tourism-centric" (Hunter, 1995), who defend the idea that sustainable tourism constitutes an economic activity in itself, and the rest, who see it more as one element of sustainable development policies in general (Cronin, 1990).

Beyond these debates on the nature of sustainable tourism development, the European Union (2007), the No. 1 worldwide tourist destination, developed its own Agenda 21 for tourism, whose objectives are:

- economic prosperity;

- equity and social cohesion; and

- protection of the environment and culture.
Pursuing these objectives in destinations that have been given over to mass tourism for 50 years assumes that the départements have implemented voluntary policies encouraged by territorial collectivities in general (Conseil Général, Communauté d'agglomération de communes, communes) and the Conseils Généraux in particular, in partnership with all stakeholder groups.

Stakeholder willingness to be involved (Hunter, 1977) in the policy development process (Hardy and Beeton, 2001) and the prevention of conflict related to the interplay of interests (Gee and Fayos-Sola, 1997) depends upon having their expectations and feelings regarding tourism heard. The degree of stakeholder involvement affects the stakeholders' influence in preparing tourism development strategies and the advantages they could derive from them, knowing that community participation remains crucial for sustainable development of tourism (Campbell, 1999, 2002; Murphy, 1988; Jones, 2005). 
As institutional actors in the economic, social and cultural life around them, territorial collectivities have an essential role to play in the development of sustainable tourism in cities, départements and regions. Unfettered by any constraints related to immediate financial profitability, they more freely initiate the innovative practices that accompany and support the renewal of tourist destination development models in the context of a carefully thought-out development of the territories.

More sensitive than any other stakeholder to financial stability, compensation and economic viability, the private sector determines its involvement in the development of sustainable tourism for a destination based on the potential market it can generate leveraging the preserved historical and natural resources (Simpson, 2008). For successful integration into the tourism dynamic for a given destination, private stakeholders maintain good relations with the other communities involved in or affected by the sustainable development of tourism (Beeton, 2006; Hawkins and Mann, 2007; UNWTO, 2005; Wearing and McDonald, 2002).

The cornerstone of developing sustainable tourism around tradition and heritage, territorial identity is of crucial importance in building and promoting a tourist destination. Thus the involvement of all stakeholders is vital because it is part of identifying the tourism product across the local specificities for which each group of actors is the bearer, organizer and ambassador. Institutional actors in tourism at the national, regional or local level furthermore gear most of their communication actions toward presenting and promoting the territorial identity in order to attract more tourists while ensuring a greater distribution of the market (Dredge and Jenkins, 2003).

At the local level, tourism activity often seems divided, fragmented and dispersed over space, generating a multitude of individual economic initiatives that do not satisfy any logic of complementarity within an overall network of actors. The identity dimension of a destination may help to bring the different stakeholder groups together around feelings of belonging or shared passions. This naturally leads tourism institutions to structure their policies for harmonizing space around the territorialization of local cultural identities (Pearce, 1992), based on the local historical and natural heritage.

While innovating consists of introducing new practices or ideas into a common action process, in the context of sustainable tourism, innovation may be built based on a destination's historical-cultural heritage, by recovering its identity as a link between past, present and future considered from the perspective of social practices that correspond to a model of sustainable economic development.

Among these social practices, the adoption of public transportation to discover a territory's cultural diversity represents genuine progress in terms of sustainable development. Introducing an efficient public transportation system provides access to heritage resources by increasing the number of visitors while limiting automobile traffic and polluting gas emissions. Since the budget that tourists allocate to transportation, lodging and living expenses in their vacation area is related to their preferences and is a matter of cost, the issue of the convenience of transportation and its price greatly influences the choice of a tourist destination (Prideaux, 2000).
We will see in this article how these factors as a whole affect the preparation of sustainable tourism development policies in the Pyrénées-Orientales, a tourist destination that is still largely given over to mass tourism.

\section{Methodology}

The reading of information brochures published by tourism organizations and consultation of their websites rounded out the reflections and knowledge shared during discussions in a professional capacity with a number of tourism actors in the Pyrénées-Orientales.

Concerning the statistical data on the use of the "1-Euro Bus" discussed in this study, contacts by email and telephone as well as a meeting with the person responsible for passengers at the Direction des Déplacements et de l'éco-mobilité (Travel and Ecomobility Department) of the Conseil Général des Pyrénées-Orientales yielded only a limited amount of reliable numerical data, given that some information was still not available or did not exist (statistics on number of passengers boarding at each stop) or could not be accessed yet because it was confidential. The data available concerned the overall number of passengers on each line, from Perpignan to the end of the line. While the success of a very low-cost public transportation route, the "1-Euro Bus", is conclusive in terms of total annual ridership, it is still difficult to carry out a qualitative study on the impact of this policy on each line and each commune served based on the available data.

Information on the policies for maintaining, showcasing and promoting historical and natural heritage was obtained by consulting websites and by reading the promotional brochures published by institutional organizations for local tourism (tourism offices, tourism committee for the département, associations and federations working for the institutions).

\section{Experiences of innovation in sustainable tourism in the Pyrénées-Orientales}

Bordered by Spain to the south, located in the LanguedocRoussillon region, the département of Pyrénées-Orientales has a population of 454,737 (INSEE, 2012) and a surface area of 4,116 square kilometres (see Figure 1). From the Mediterranean coast to the snowy peaks of the Pyrenees Mountains, the region's geographical advantages and extensive history are revealed in a wide variety of landscapes whose natural beauty is reinforced by a rich historical heritage. These assets have made the Pyrénées-Orientales the $7^{\text {th }}$ most popular département in France for tourism, with more than 33 million overnight stays (ODT Pyrénées-Orientales, 2011).

These days, the survival and revitalization of outlying rural areas involve social and economic policies for spatial cohesion to ensure more balanced competitiveness among the territories. As Léon Bertrand (2005, translation), the former French Minister for Tourism, pointed out: "in a wide variety of situations, tourism offers an opportunity to create added value for each rural territory, while helping safeguard its environmental wealth and strengthen its social foundation, according to the principles of sustainable development." In the Pyrénées-Orientales, three important actions spearheaded and maintained by the Conseil Général have directly contributed to the development 
Figure 1 : Presentation and location of the département of Pyrénées-Orientales (source : Gildas Girodeau for this study).

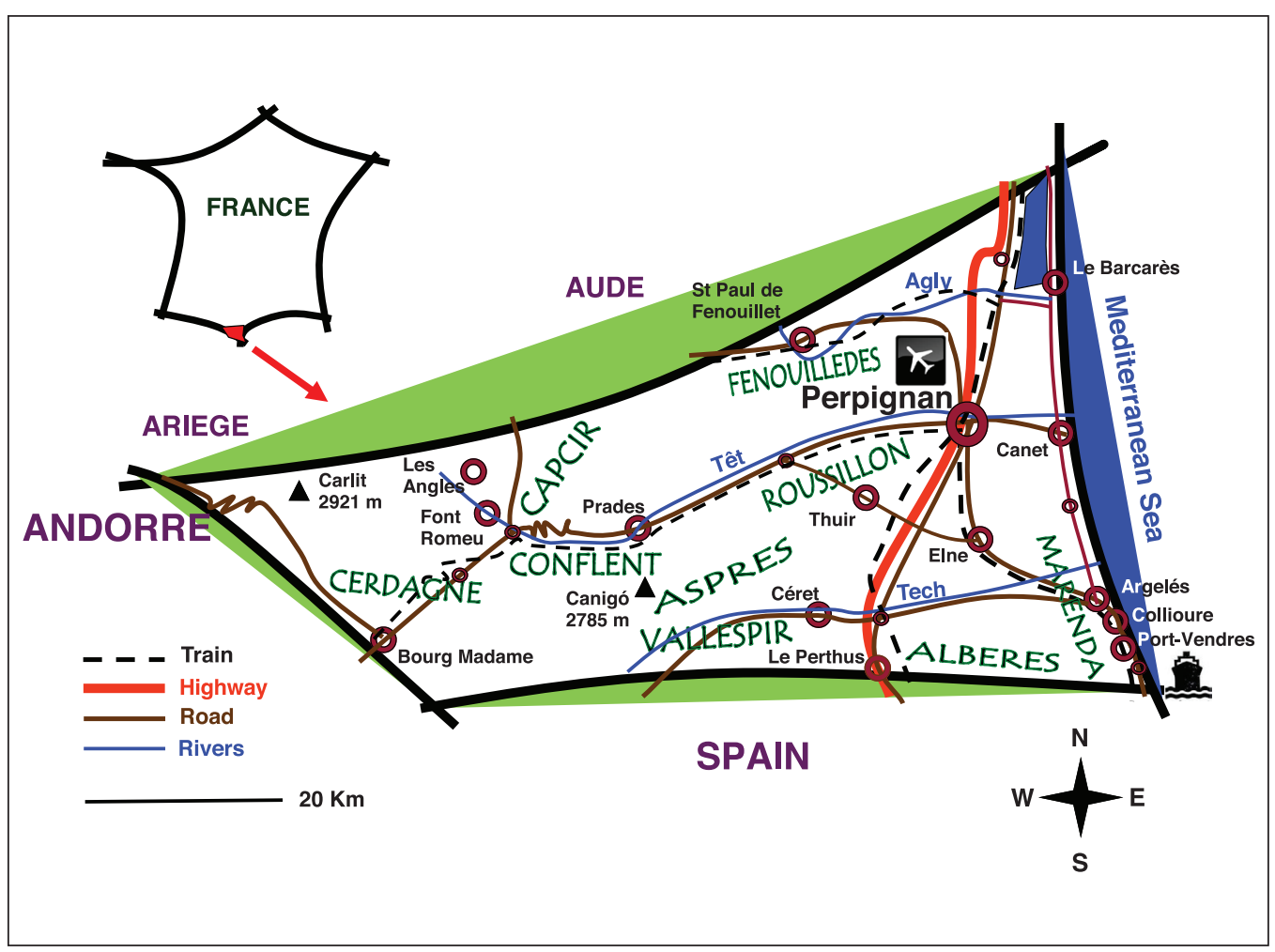

of sustainable tourism at the level of the département, namely: 1) optimizing the redistribution of benefits related to tourism activity by federating the stakeholders; 2) encouraging mobility by facilitating access to the various tourist sites in the département through a 1-euro bus; 3 ) making cross-border cooperation central to sustainable tourism development.

\section{Optimizing the redistribution of benefits related to tourism activity by federating the stakeholders}

The Réseau Culturel association (www.reseauculturel.fr) was created in the 1990s with the aim of placing the Catalan heritage of the Pyrénées-Orientales at the centre of its tourist development dynamic. By federating the heritage sites, networking the actors and developing training for tourism technicians, the Réseau Culturel Terres Catalanes has already increased the visibility of the unique cultural product which is the sum of the local heritage, among other things through the annual publication of the "Intersites Pass" guide that offers discounts on admission to the various sites affiliated with the Réseau Culturel.

By getting craftspeople, farmers, hoteliers and restaurateurs a little more involved each year in the process of highlighting traditions and expertise, the Tourisme de Terroir federation (www.tourismedeterroir.fr) helps to promote tourism in the Pyrénées-Orientales through the area's local natural and gourmet products. From March through September, travelling apéritif parties featuring local wines give many professionals an opportunity to make contact with the various tourist segments, while at the same time promoting the different regions within the département.
Encouraging mobility by facilitating access to the various tourist sites in the département. the "1-Euro Bus"

Developing a model for sustainable tourism in a département adjacent to the Spanish border like the Pyrénées-Orientales means being able to deal with extremely heavy automobile traffic in peak tourist season. To limit the impact of transportation on the environment and to provide better access to the département's heritage resources, a bold and ambitious public transportation policy was considered, decided, planned and then implemented by the Conseil Général des Pyrénées-Orientales. Until that time, the département's bus lines were lacking, not well suited to the needs of public transportation users, and played only a symbolic role in the territory's development and structure. Innovation came at the instigation of the Conseil Général des Pyrénées-Orientales with the launch on November 1, 2008 of the "1-Euro Bus": one euro for everyone, all the time and all year round, throughout the Pyrénées-Orientales territory. The innovation was the symbolic flat fare of one euro. By relying on a substantial reduction in ticket price and having a standard fare, the Conseil Général helped to considerably boost passenger traffic (see Figures 2 and 3) while containing operating deficits.

A year after the "1-Euro Bus" was launched, Patrice Rémy (Belmont, 2009), the former manager of transportation for the Conseil Général, and the new manager of the PyrénéesOrientales tourism committee, stated that in 2008 (translation), "bus receipts totalled 900,000 euros. The budget line will be exactly the same this year. The increase in ridership has compensated for the reduction in price. We even succeeded in gaining the loyalty of new users. To balance the accounts, service 

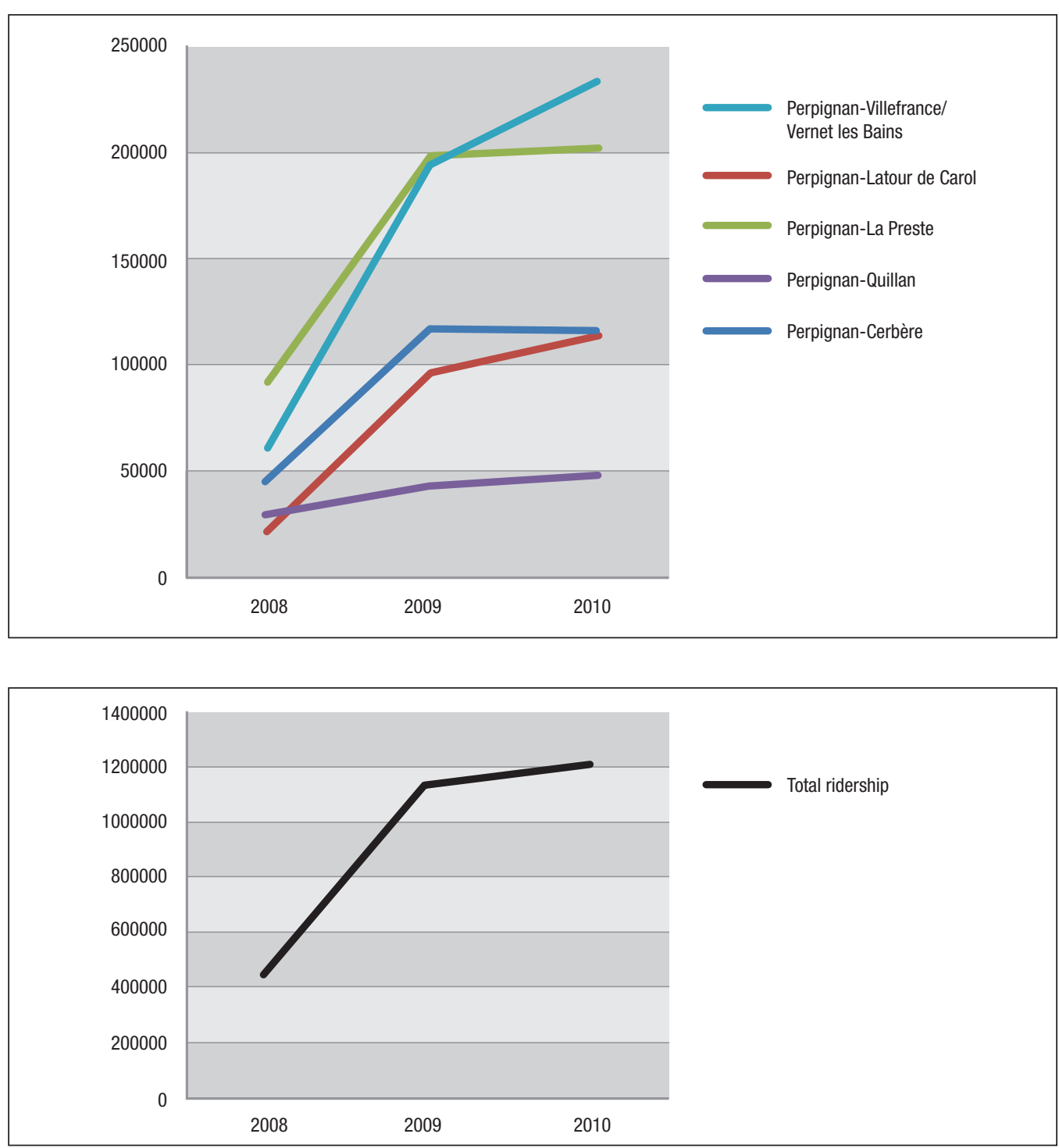

Figure 2: Changes in passenger traffic on the département's main "1-Euro Bus" lines between 2008 and 2010 (source : Conseil Général des Pyrénées-Orientales (2012)).
Figure 3 : "1-Euro Bus" network between 2008 and 2010 (source : Conseil Général des Pyrénées-Orientales (2012)). areas were rationalized, specifically by replacing regular lines with on-demand service in order to avoid having buses travelling empty. In 2012, all the communes will be served in this manner." The popularity of the "1-Euro Bus" with tourists can be seen each summer through a sharp rise in passenger traffic. Increased and sustained demand for information on bus schedules and routes can also be observed at tourist bureaus on the part of vacationers who want to take advantage of the opportunity to tour the territory at a lower cost. This new spatial mobility generates a dynamic of openness and integrates the backcountry. It favours new cooperation between territories and thereby helps to maintain the backcountry's economic and social fabric while enhancing the structure of the département and its territory.

In the wake of the success of the "1-Euro Bus" in the Pyrénées-Orientales and Alpes-Maritimes, 29 other départements have chosen to introduce a flat fare, of between 1.50 and 2 euros.

\section{Making cross-border cooperation central to sustainable development of tourism}

At the centre of the territories' economic, social and cultural life, a certain type of tourism facilitates discussions and meetings between professional actors and helps them set up the social networks that constitute the first step in building cross-border cooperative projects that target commonly shared problems. Taken in a cross-border context, the tourist discussion raises issues relating to sustainable development, maintaining and showcasing historical, cultural and natural heritage, as well as issues related to promoting territories as integrated tourist destinations.

Considering the Romanesque heritage of landscapes without borders, it was important, for smooth management of heritage resources and in order to showcase the Catalan identity, to work in partnership with Catalonia by taking advantage of the European cohesion funds (FEDER, INTERREG) set up to foster cross-border cooperation. This showcasing 
of identity was done through the creation of the first crossborder Pays d'Art et d'Histoire (Land of Art and History) bringing together the comarques (or counties, the historical administrative territories of Catalonia) of Vallespir, on the French side, and Alt Empordà, Garrotxa and Ripollès, on the Spanish side. In summer 2011, a number of guided heritage tours were organized in Catalan and in French on both sides of the border, which permitted tourism development actions to be carried on in a culturally relevant and homogeneous cross-border space, and all as part of a sustainability process. The guided tours will continue in summer 2012 with an offering similar to the one in 2011.

\section{Conclusion}

While the backcountry of the Pyrénées-Orientales has long remained on the fringes of the explosive development of the département's coast, today it symbolizes the renewal of a Mediterranean destination that has been constructing itself according to a sustainable model of tourism development. Protected from the impact of mass tourism by its geographical and economic isolation, the backcountry today represents an essential asset for promoting the Pyrénées-Orientales through its rich heritage and the preservation of its natural setting. Built around a network of actors, the implementation of public transportation initiatives and the promotion of local historical and natural heritage, sustainable tourism development affects regional and territorial balances and as a result constitutes a territorial development issue. From mass tourism to sustainable tourism, the département of Pyrénées-Orientales is now shaping itself as a global tourism destination that integrates its different regions by showcasing all its geographical and historical wealth. "Think globally, act locally" - a simple idea, summed up in this well-known formula which is a reminder that any sustainable development ambitions at the international level must be followed by concrete actions at the local level.

\section{References}

BEETON, Sue (2006) Community Development Through Tourism, Victoria

(Australia): Landlinks Press. 246 p.

BELMONT, Claude (2009) "Succès pour le Bbus à 1 Euro

dans les Pyrénées-Orientales”, <http://www.lefigaro.fr/

conjoncture/2009/11/24/04016-20091124ARTFIG00434-succes-pour-

le-bus-a-1-euro-dans-les-pyrenees-orientales-.php $>$, retreived on

01.03.2012

BERTRAND, Léon (2005) Le Tourisme, Outil de Revitalisation des Territoires Ruraux et de Développement Durable?, foreword, Paris : La Documentation Française. 288 p.

CAMPBELL, Lisa M. (1999) "Ecotourism in Rural Developing Communities", Annals of Tourism Research, vol. 26, n 3, pp. 534-553.

CAMPBELL, Lisa M. (2002) "Conservation Narratives and the Received Wisdom of Ecotourism: Case Studies from Costa Rica", International Journal of Sustainable Development, vol. 5, n 3, pp. 300-325.

CONSEIL GÉNÉRAL DES PYRÉNÉES-ORIENTALES (2012) Direction des Déplacements et de l'Eco-mobilité, Pôle Voyageurs.

CRONIN, Linda (1990) "A Strategy for Tourism and Sustainable Tourism", World Leisure and Recreation, vol. 32, n 3, pp. 12-18.

DREDGE, Dianne and John JENKINS (2003) "Destination Place Identity and Regional Tourism Policy”, Tourism Geographies, vol. 5, n 4, pp. 383-407.
EUROPEAN UNION (2007) "Agenda pour un Tourisme Européen Compétitif et Durable", Europa - Synthèses de la législation de l'UE, <http://europa. eu/legislation_summaries/enterprise/ industry/l10132_fr.htm>, retrieved on 01.03.2012.

GEE, Chuck Yim and Eduardo FAYOS-SOLA (1997) "International Tourism: a Global Perspective”, Madrid: World Tourism Organization, Madrid. 406 p.

GIRODEAU, Gildas (2012) Département des Pyrénées-Orientales. Map made for this publication.

HAWKINS, Donald E. and Shaun MANN (2007) “The World Bank's Role in Tourism Development", Annals of Tourism Research, vol. 34, $n^{\circ}$ 2, pp. 348-363.

HARDY, Anne and Robert J.S. BEETON (2001) "Sustainable Tourism or Maintainable Tourism: Managing Resources for More than Average Outcomes", Journal of Sustainable Tourism, vol. 9, n 3, pp. 168-192.

HUNTER, Colin (1995) "On the Need to Re-Conceptualise Sustainable Tourism Development”, Journal of Sustainable Tourism, vol. 3, n 3, pp. 155-165.

HUNTER, Colin (1997) "Sustainable Tourism as an Adaptive Paradigm", Annals of Tourism Research, vol. 24, $\mathrm{n}^{\circ}$ 4, pp. 850-867.

INSEE - Institut national de la statistique et des études économiques (2012) "Populations Légales 2009 des Pyrénées-Orientales", Institut national de la statistique et des études économiques, $<$ http://www.insee.fr/fr/ppp/basesde-donnees/recensement/populations-legales/ departement.asp?dep $=66>$, retrieved on 01.03.2012.

JONES, Samantha (2005) "Community-Based Ecotourism: the Significance of Social Capital", Annals of Tourism Research, vol. 32, n² 2, pp. 303-324.

MURPHY, Peter E. (1988) “Community Driven Tourism Planning”, Tourism Management, vol. 9, n 2, pp. 96-104.

ODT Pyrénées-Orientales (2011) “Chiffres Clés du Tourisme des PO en 2010", Comité départemental du tourisme Pyrénées-Orientales, $<$ http:// observatoire-cdt66.typepad.fr/outils/ chiffres_cls/index.html $>$, retrieved on 01.03.2012.

PEARCE, Douglas G. (1992) Tourist Organizations, Harlow: Longman Scientific and Technical. $219 \mathrm{p}$.

PRIDEAUX, Bruce (2000) "The Role of the Transport System in Destination Development”, Tourism Management, vol. 21, n 1, pp. 53-63.

RÉSEAU CULTUREL (2012) “Qui Sommes-Nous?”, Réseau Culturel Terres Catalanes, $<$ http://www.reseauculturel.com/articles. asp?lng=FR\&id $=4875>$, retrieved on 01.03.2012.

SHARPLEY Richard and David J. TELFER (editors), (2002) Tourism and Development: Concepts and Issues, Clevedon, England: Aspects of Tourism series, Channel View publications. $408 \mathrm{p}$.

SIMPSON, Murray (2008) "Community Benefit Tourism Initiatives - a Conceptual Oxymoron?”, Tourism Management, vol. 29, nº 1, pp. 1-18.

Tourisme de Terroir (2012) "Un Réseau, une Marque, un Engagement", Fédération départementale de Tourisme de Terroir, <http://www. tourismedeterroir.fr/Un-reseau-une-marque-un-engagement--5598. phtm?lng=FR $>$, retrieved on 01.03.2012.

UNWTO - United Nations World Tourism Organization (2005) "Making Tourism More Sustainable: A Guide for Policy Makers", Madrid, Spain, UNWTO.

WEARING, Stephen and Matthew McDONALD (2002) “The Development of Community-Based Tourism: the Relationship Between Tour Operators and Development Agent as Intermediaries in Rural and Isolated Communities", Journal of Sustainable Tourism, vol. 10, n 3, pp. 191-206. 